\title{
Simulation and Optimization of Hybrid Diesel Power Generation System for GSM Base Station Site in Nigeria
}

\author{
Ani Vincent Anayochukwu ${ }^{1 *}$ Emetu Alice Nnene ${ }^{2}$ \\ 1 Department of Electronic Engineering, University of Nigeria, Nsukka, Nigeria. \\ ${ }^{2}$ Department of Nutrition and Dietetics, University of Nigeria, Nsukka, Nigeria. \\ * Corresponding author: Email: vincent_ani@yahoo.com. Phone Number: \\ +2348054024629 .
}

ABSTRACT The telecommunications industry requires efficient, reliable and cost-effective hybrid systems as alternatives to the power supplied by diesel generators. This investigation proposes a solar - photovoltaic $(\mathrm{PV}) /$ diesel hybrid power generation system suitable for Global System for Mobile communication (GSM) base station site. The study is based on simulation and optimization of a hybrid system for a GSM base station site located in Abuja (FCT), Nigeria with a daily load of $318 \mathrm{kWh} \mathrm{d}^{-1}$. Solar radiation for the design of the system was obtained from NASA surface Meteorology and solar energy website at a location of $9^{\circ} 00^{\prime} \mathrm{N}$ latitude and $7^{\circ} 00^{\prime} \mathrm{E}$ longitude, with annual average solar radiation of $5.45 \mathrm{kWh} \mathrm{m}^{-2} \mathrm{~d}^{-1}$. Hybrid Optimization Model for Electrical Renewables (HOMER) software was used for the design of the proposed power system. The study evaluates savings associated with conversion of the diesel powered system to a PV/diesel hybrid power system. From the simulation results, the proposed system has total Net Present Cost (NPC) and amount of $\mathrm{CO}_{2}$ as (\$995,774; 65.270 tonnes), and saves (\$716,397; 57.835 tonnes) when compared with the diesel only system $(\$ 1,712,171 ; 123.105$ tonnes). A control system for the hybrid PV-diesel energy system with battery storage was developed to coordinate when power should be ge-
Received 11 January 2013; revision received 03 March 2013; accepted 05 March 2013. Published online 30 April 2013 (www.ejee.cl). DOI 10.7770/ejee-V1N1-art481.

๑) Renewable Energies Research Nucleus, UC Temuco.

nerated by PV panels and when it should be generated by diesel generator. This hybrid system could be applied in any other electrical system.

KEYWORDS Hybrid system, power supply, solar-PV, control strategy, optimization algorithm, HOMER, Abuja (FCT).

\section{Introduction}

Power supply is one of the critical challenges confronted by telecommunications operators in deploying their networks [Ani and Emetu, 2013a]. This challenge is readily overcome in developed countries as a result of up-to-date power infrastructure. In the developing world, where a national electricity grid exists, it is always the energy solution of choice for powering Base Transceiver Stations (BTSs). Unfortunately, it is not always reliable and has limited coverage. This is even more complicated in developing countries like Nigeria. Providing dedicated, reliable low-cost power supply for base station sites in Nigeria is very challenging, as most of the areas are not connected to the electricity grid. Even when they are 
connected, the availability of supply is very limited in order to provide uninterrupted power supply to satisfy minimum requirements of Quality of Service (QoS). Airtel Nigeria (Mobile Operator) reports that non-availability of regular grid power supply to sites across the country is responsible for over $70 \%$ of down time, resulting in poor QoS [Vanguard News Paper, 2011]. The company is now in the process of upgrading 250 sites to be diesel-powered.

Presently, the problem of poor electricity supply experienced at telecom installations in Nigeria is being resolved by diesel generators. These generators, however, are associated with many problems. These include, among others, noise pollution emanating from the generators and environmental pollution. Diesel generator exhaust contains harmful hydrocarbons in the atmosphere during operations. Operation and maintenance is costly, and typically accounts for 35 percent of the total cost of ownership (TCO) (ALCATEL-LUCENT) of a BTS. MTN Nigeria, one of the four mobile telecoms operators in Nigeria with 4,798 base stations, spends a whopping $\$ 82.8$ million on generator acquisition almost every three years, and \$3.5 million monthly on diesel-oil and generator maintenance [IT News Africa, 2010]. This puts the OPEX of generators and diesel at about $\$ 69$ million annually. Engineer Eyo Ita affirmed that global system for mobile communication (GSM) operators had spend over $\$ 3,086.42$ on diesel generators in each of their base stations - roughly five hundred and twenty base stations with costs being transferred to subscribers in terms of billing [Melford, 2003].

Taking into consideration the excess cost of normal operation that the utilization of diesel generating sets brings to the operators, it is inevitable that consumers pay more for mobile service. Taking into consideration the excess cost of normal operation that the utilization of diesel generating sets brings to the operators, it is inevitable that consumers pay more for mobile service. Wireless telephone users in Nigeria were meant to believe right from the time when GSM/wireless telephony became fully integrated into Nigerian society in 2001, that it was due to rising cost of operations (high cost of diesel) that made calls to be costly.
While the consumers cry foul, the operators had been defending the reason why high-call-cost should continue perpetually.

Apart from high call cost that is blamed on high operational cost, poor service is also linked with use of diesel generating sets, due to down-times because of maintenance and breakdown Thus, it is increasingly evident that diesel-powered stations are becoming a much less viable option for network operators.

Hybridizing diesel with renewable energy sources (solar and/or wind power) is one method of reducing call cost and improving the service of wireless telephony in terms of powering base station sites. This will allow telecom companies to circumvent rising energy costs and receive an excellent Return on Investment (ROI) [Ani, 2013b]. It will also make communications more accessible and reduce the environmental impact. A hybrid power system is therefore proposed to solve these aforementioned problems.

\section{Hybrid power systems (HPS)}

A hybrid powered system can be described as an electricity production system in which energy supply consists of a combination of two or more types of electricity generating sources (e.g. solar photovoltaic panels, wind turbine generators, pico-hydro plants, and/or fuel generators). The components utilized in the hybrid system considered in this study are solar photovoltaic panels and a diesel generator. A diesel generator can provide energy at any time, whereas energy from PV is greatly dependent on the availability of solar radiation [Wichert, 1997; Yu et al. 2005]. This makes the system (generator) more reliable, and can be used for operation when the PV fail to satisfy the load and when the battery storage is depleted.

A hybrid system uses advanced system control logic (also known as a dispatch strategy) to coordinate when power should be generated by renewable energy and when it should be generated by sources like diesel generators. The real innovation of hybrid power generation is understanding that cost savings do not come from using the most powerful solar panels or the most efficient diesel engine, but by closely 
matching the cheapest energy production with the load. By coupling and coordinating sources together, the system provides more reliable and higher quality electricity at lower costs [Faruk et al. 2012]. The hybrid system that was optimized in this study is PV/ diesel.

The purpose of this study was to hybridize the existing energy (diesel generator source) system with renewable energy (PV panels) through design and optimization. This study also examines the effect of hybridized diesel generator on:

- The cost of generating energy (Total net present cost (NPC)).

- The operational hours of diesel generator.

- The reduction in greenhouse gas (GHG) emission cost $\left(\$ / t^{-1}\right)$

The aim is to determine the suitability of hybrid $\mathrm{PV} /$ diesel system with battery in the telecommunications industry, from the perspective of technical and economical analysis.

\section{Renewable energy sources}

\section{Photovoltaic energy}

Nigeria is a tropical country which lies between $4^{\circ}$ and $13^{\circ}$, approximately, with a landmass of $9.24 \times 105$ $\mathrm{km}^{2}$. Nigeria enjoys an average daily sunshine of 6.25 $\mathrm{h}$, ranging between about $3.5 \mathrm{~h}$ at the coastal areas and $9.0 \mathrm{~h}$ at the far northern boundary [Bala et al. 2000]. Its climate varies from tropical to subtropical. There are two main seasons; the dry season lasting from October to March and the rainy season lasting from April to October. In the north, it is hot and dry, and the rainy season extends between April and September. In the south, it is hot and wet, and the rainy season extends between March and December. From December to March there is a long dry season [Ojo, 2000]. Temperatures on the coast rarely rise above $32{ }^{\circ} \mathrm{C}$. The north is drier, with temperature ranging between $32{ }^{\circ} \mathrm{C}$ and $42{ }^{\circ} \mathrm{C}$. Humidity is about $95 \%$ [Falade, 1995]. The terrestrial radiation on Nigeria's land area is $2.079 \times 1015 \mathrm{kWh}$ year ${ }^{-1}$. Solar energy is one of the inexhaustible energy sources available for the implementation of renewable energy systems for telecommunications in Nigeria. Therefore, the integration of solar photovoltaic with a readily available standalone diesel generator (or generally known as the hybrid PV/diesel system) has potential application in the telecommunications industry.

\section{Wind resource}

Wind speed is relatively weak in the study area with an average of $2.4 \mathrm{~m} \mathrm{~s}^{-1}$ throughout the year. Therefore, wind resource is extremely low at this site and this investigation will not include a wind turbine option.

\section{Energy consumptions}

In identifying the energy consumption at GSM base station sites and assessing the impact of various operational strategies, a macro BTS was used as a model. A BTS is a tower or mast, mounted with telecommunication equipment (e.g. antenna, radio receiver and transmitters at the top of the mast) that enables the transmission of mobile signals (voice and data) [Ani and Emetu, 2013a]. At the bottom of each tower, there is a shelter with additional transmission equipment, air conditioning, battery racks and - for those that are off-grid or with unreliable electricity supplyin a separate room, the diesel generator [Ani, 2013b]. A BTS site load profile depends on multiple parameters including radio equipment, antenna, power conversion equipment, transmission equipment, among others. Therefore, it is important to outline an accurate power profile in order to select energy components and their sizing. The energy consumption of the various components at a typical Radio Base Station (RBS) site is categorized by [Pierre, 2006; Roy, 2008; Willson, 2009; GSMA, 2009; Ani and Nzeako, 2012] as follows:

\section{Radio equipment:}

- Radio Unit [Radio Frequency (RF) Conversion and Power Amplification] $=4160 \mathrm{~W}$

- Base Band [Signal Processing and Control] = $2190 \mathrm{~W}$

\section{Power conversion equipment:}


Table 1 Load estimation of the base station site.

\begin{tabular}{|c|c|c|c|c|c|}
\hline $\begin{array}{l}\text { GSM base station site power equipment } \\
\text { description }\end{array}$ & $\begin{array}{l}\text { Rated power } \\
\text { Watt }\end{array}$ & BTU $h^{-1}$ & QTY & $\begin{array}{l}\text { Net power in } \\
\text { Watt } h^{-1}\end{array}$ & $\begin{array}{l}\text { Net power in } \\
\text { BTU } h^{-1}\end{array}$ \\
\hline \multicolumn{6}{|l|}{ Radio equipment: } \\
\hline Radio unit & 4160 & 14186 & 1 & 4160 & 14186 \\
\hline Base band & 2190 & 7468 & 1 & 2190 & 7468 \\
\hline \multicolumn{6}{|l|}{ Power conversion equipment: } \\
\hline Power supply and rectifier & 1170 & 3990 & 1 & 1170 & 3990 \\
\hline \multicolumn{6}{|l|}{ Antenna equipment } \\
\hline RF feeder & 120 & 409 & 1 & 120 & 409 \\
\hline Remote monitoring and safety & 100 & 341 & 1 & 100 & 341 \\
\hline \multicolumn{6}{|l|}{ Transmission equipment } \\
\hline Signal transmitting & 120 & 409 & 1 & 120 & 409 \\
\hline \multicolumn{6}{|l|}{ Auxiliary equipment } \\
\hline Security and lighting & 200 & 682 & 1 & 200 & 682 \\
\hline Total & & & & 8060 & 27485 \\
\hline
\end{tabular}

- Power Supply \& Rectifier $=1170 \mathrm{~W}$

3. Antenna equipment

- $\mathrm{RF}$ feeder $=120 \mathrm{~W}$

- Remote Monitoring and Safety (aircraft warning light $)=100 \mathrm{~W}$

4. Transmission equipment

- Signal Transmitting $=120 \mathrm{~W}$

5. Auxiliary equipment

Security and Lighting $=200 \mathrm{~W}$

\section{Climate equipment}

Base stations require a high level of cooling capacity given that the electricity used to power the electronic and other equipment is converted to heat and requires removal [Robertson et al. 2002; Ani et al. 2012]. Air conditioning systems are typically air-cooled, distributed throughout the Cabin (shelter) to ventilate and cool the servers and other equipment. The cooling capacity of an air-conditioning unit is the ability to remove heat from a room, and is usually measured in BTU $h^{-1}$. The higher the BTU rating, the more heat will be removed (BTU Definition \& Calculate BTU).
Optimization of climate equipment (air-conditioner BTU capacity) for a GSM base station shelter

The cooling architecture is designed to address heat generation from radio equipment, power conversion equipment and other heat equipment.

List of air-conditioner BTU rating:

9,000 BTU

$12,000 \mathrm{BTU}$

$15,000 \mathrm{BTU}$

$18,000 \mathrm{BTU}$

21,000 BTU

24,000 BTU

And so on... (BTU Definition \& Calculate BTU).

Table 1 shows that the ideal power rating, i.e., power consumption of base station equipment, is $8,060 \mathrm{~W} \mathrm{~h}^{-1}$.

Cooling requirement for the base station equipment, i.e., power required to remove heat from the base station shelter as shown in Table 1 is 27485 BTU $\mathrm{h}^{-1}$.

It is assumed that the base stations work for 24 h (00:00 h - 23:59 h) per day. The RF feeder, remote monitoring, and safety lighting (aircraft warning 
Table 2 The electrical load (daily load demands) data for the base station site.

\begin{tabular}{|c|c|c|c|c|c|c|c|c|c|}
\hline \multirow[b]{2}{*}{ Time } & \multicolumn{8}{|c|}{ DAILY LOAD DEMANDS } & \multirow[b]{2}{*}{ Total $h^{-1}$} \\
\hline & $\begin{array}{c}\text { Radio } \\
\text { unit }\end{array}$ & $\begin{array}{l}\text { Base } \\
\text { band }\end{array}$ & $\begin{array}{c}\text { Power } \\
\text { supply \& } \\
\text { rectifier }\end{array}$ & RF feeder & $\begin{array}{c}\text { Remote } \\
\text { monitor- } \\
\text { ing and } \\
\text { safety }\end{array}$ & $\begin{array}{l}\text { Signal } \\
\text { transmit- } \\
\text { ting }\end{array}$ & $\begin{array}{c}\text { Security } \\
\text { and } \\
\text { lighting }\end{array}$ & $\begin{array}{c}\text { Climate } \\
\text { equip- } \\
\text { ment }\end{array}$ & \\
\hline 00-01 & 4160 & 2190 & 1170 & 120 & 100 & 120 & 200 & 5274 & 13334 \\
\hline 01-02 & 4160 & 2190 & 1170 & 120 & 100 & 120 & 200 & 5274 & 13334 \\
\hline $02-03$ & 4160 & 2190 & 1170 & 120 & 100 & 120 & 200 & 5274 & 13334 \\
\hline 03-04 & 4160 & 2190 & 1170 & 120 & 100 & 120 & 200 & 5274 & 13334 \\
\hline 04-05 & 4160 & 2190 & 1170 & 120 & 100 & 120 & 200 & 5274 & 13334 \\
\hline $05-06$ & 4160 & 2190 & 1170 & 120 & 100 & 120 & 200 & 5274 & 13334 \\
\hline $06-07$ & 4160 & 2190 & 1170 & 120 & 100 & 120 & 200 & 5274 & 13334 \\
\hline $07-08$ & 4160 & 2190 & 1170 & 120 & 100 & 120 & & 5274 & 13134 \\
\hline 08-09 & 4160 & 2190 & 1170 & 120 & 100 & 120 & & 5274 & 13134 \\
\hline $09-10$ & 4160 & 2190 & 1170 & 120 & 100 & 120 & & 5274 & 13134 \\
\hline $10-11$ & 4160 & 2190 & 1170 & 120 & 100 & 120 & & 5274 & 13134 \\
\hline $11-12$ & 4160 & 2190 & 1170 & 120 & 100 & 120 & & 5274 & 13134 \\
\hline $12-13$ & 4160 & 2190 & 1170 & 120 & 100 & 120 & & 5274 & 13134 \\
\hline $13-14$ & 4160 & 2190 & 1170 & 120 & 100 & 120 & & 5274 & 13134 \\
\hline $14-15$ & 4160 & 2190 & 1170 & 120 & 100 & 120 & & 5274 & 13134 \\
\hline $15-16$ & 4160 & 2190 & 1170 & 120 & 100 & 120 & & 5274 & 13134 \\
\hline $16-17$ & 4160 & 2190 & 1170 & 120 & 100 & 120 & & 5274 & 13134 \\
\hline $17-18$ & 4160 & 2190 & 1170 & 120 & 100 & 120 & & 5274 & 13134 \\
\hline $18-19$ & 4160 & 2190 & 1170 & 120 & 100 & 120 & 200 & 5274 & 13334 \\
\hline $19-20$ & 4160 & 2190 & 1170 & 120 & 100 & 120 & 200 & 5274 & 13334 \\
\hline $20-21$ & 4160 & 2190 & 1170 & 120 & 100 & 120 & 200 & 5274 & 13334 \\
\hline $21-22$ & 4160 & 2190 & 1170 & 120 & 100 & 120 & 200 & 5274 & 13334 \\
\hline $22-23$ & 4160 & 2190 & 1170 & 120 & 100 & 120 & 200 & 5274 & 13334 \\
\hline $23-00$ & 4160 & 2190 & 1170 & 120 & 100 & 120 & 200 & 5274 & 13334 \\
\hline Total & 99840 & 52560 & 28080 & 2880 & 2400 & 2880 & 2600 & 126576 & 317816 \\
\hline
\end{tabular}

light) are all located outside the cabin, and do not quirement for $24 \mathrm{~h}=26,053 \times 24=625,272 \mathrm{BTU} \mathrm{d}^{-1}$. contribute to the heat accumulated inside the cabin.

From the list of air-conditioner BTU rating stated

Therefore, the net power from these instruments was subtracted from the total Net Power in $\mathrm{BTU} \mathrm{h}^{-1}$ as $[27485-(682+409+341)]=26,053 \mathrm{BTU} \mathrm{d}^{-1}$. The total above, 18,000 BTU was chosen.

The air conditioning system size required to serve Net Power in BTU h ${ }^{-1}$ is 26,053 BTU d $^{-1}$. Cooling re- 


$$
\frac{625,272}{18,000} \times \frac{1}{24}=1.5
$$

The cooling system is comprised of a split-unit solar air conditioner with a rating of $1.5 \mathrm{hp}$.

Energy required in removing heat from the base station shelter (cabin).

Cooling requires the majority of the energy generated. The air conditioning required for the project is splitcool DC18. The consumption of DC 18 in Wattage $=18,000 \times 0.293=5,274 \mathrm{~W} \mathrm{~h}^{-1}$.

Consumption for $24 \mathrm{~h}$ in Wattage $=5,274 \times 24=$ $126,576 \mathrm{~W} \mathrm{~d}^{-1}$.

The electric power needed for the base station equipment in and the energy required to remove heat from the shelter (cabin) are stated below.

- Base station site equipment power requirement $=8,060 \mathrm{~W} \mathrm{~h}^{-1}$.

- Climate equipment power requirement $=5,274$ $\mathrm{W} \mathrm{h}^{-1}$.

Therefore, the total power requirement for the GSM base station site $=13,334 \mathrm{~W} \mathrm{~h}^{-1}$.

This implies that as a generalization, a GSM site consumes $13.3 \mathrm{kWh}$ of electricity.

Load variation of the GSM base station site.

The slight changes as well as the flat lines for extended periods of time in Fig. 1 are realities of daily electricity consumption of the GSM base station site under study. All equipment (radio equipment, power conversion equipment, antenna equipment, transmission equipment, and climate equipment) at the base station site runs for $24 \mathrm{~h}(00: 00 \mathrm{~h}-23: 59 \mathrm{~h})$, except the auxiliary equipment (security light) that runs for $13 \mathrm{~h}$ $(18: 00 \mathrm{~h}-7: 00 \mathrm{~h})$. It is assumed that energy consumption is identical for every day of the year. The annual peak load of $13 \mathrm{~kW}$ was observed between 18:00 h and 07:00 h, with $318 \mathrm{KWh} \mathrm{d}^{-1}$ energy consumption. The daily average load variation for the base station site is shown in Fig. 1 and Table 2.

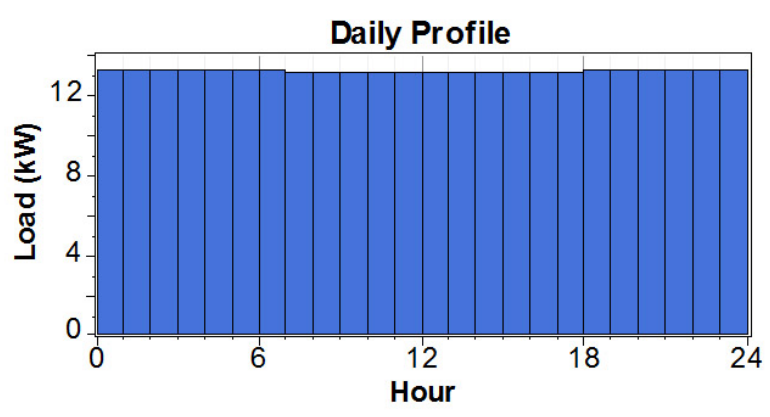

Figure 1 Daily profile of electricity consumption at the GSM base station site.

Table 3 Solar resource for Abaji (Abuja, FCT).

\begin{tabular}{|lcc|}
\hline Month & $\begin{array}{c}\text { Clearness } \\
\text { index }\end{array}$ & $\begin{array}{c}\text { Average radiation } \\
\text { (kWh } \mathbf{~}^{-2} \mathbf{~ d}^{-1} \text { ) }\end{array}$ \\
\hline Jan & 0.652 & 5.880 \\
Feb & 0.630 & 6.090 \\
Mar & 0.610 & 6.270 \\
Apr & 0.577 & 6.060 \\
May & 0.539 & 5.580 \\
Jun & 0.497 & 5.060 \\
Jul & 0.434 & 4.440 \\
Aug & 0.404 & 4.190 \\
Sep & 0.460 & 4.730 \\
Oct & 0.542 & 5.310 \\
Nov & 0.655 & 5.980 \\
\hline Dec & 0.668 & 5.860 \\
\hline Scaled annual & & 5.450 \\
average & & \\
\hline
\end{tabular}

\section{Study area}

The study area contemplates the energy optimization at as GSM base station site presently run by a standalone diesel generation system. The site is located in Abaji (Abuja, FCT) at a location of $9^{\circ} 00^{\prime} \mathrm{N}$ latitude and $7^{\circ} 00^{\prime} \mathrm{E}$ longitude with annual average solar daily radiation of $5.45 \mathrm{kWh} \mathrm{m}^{-2} \mathrm{~d}^{-1}$. The data for the solar resource were obtained from the NASA surface meteorology and solar energy web site [NASA, 2010]. For this study, only PV technology was considered in terms of renewable energy. Fig. 2 shows the solar resource profile of this location. 


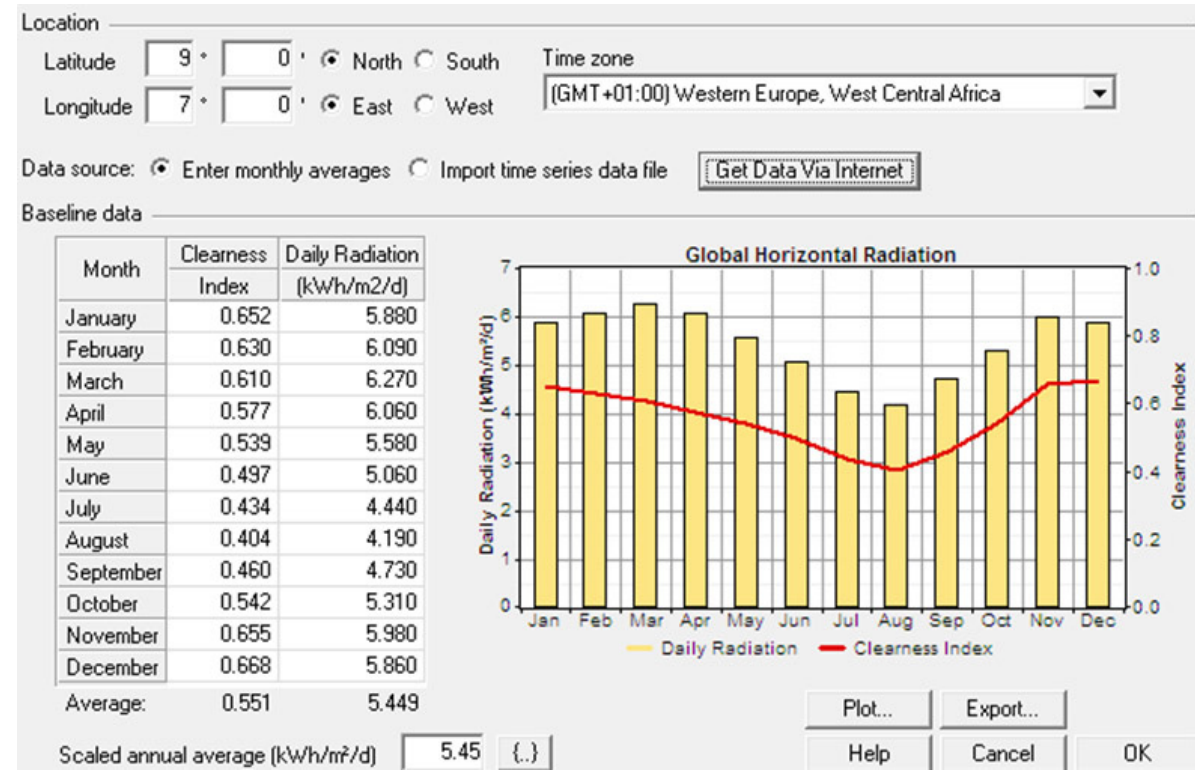

Figure 2 Solar resource (clearness index and daily radiation) profile for Abaji (Abuja, FCT).

\section{Solar radiation variation}

March is the sunniest month of the year, in which the solar energy resource is measured to be $6.3 \mathrm{kWh}$ $\mathrm{m}^{-2} \mathrm{~d}^{-1}$ while in August it is $4.2 \mathrm{kWh} \mathrm{m}^{-2} \mathrm{~d}^{-1}$ as shown in Fig. 2 and Table 3. In the months of March, April, May, June, July and November, the solar radiation increases with differences from month to month as (0.21), (0.48), (0.52), (0.62), (0.25), and (0.12) respectively. Whereas in the months of January, February, August, September, October, and December, the solar radiation decreases with differences from month to month as $(0.21),(0.18),(0.54),(0.58),(0.67)$, and $(0.02)$ respectively. In these months, the diesel generator can compensate.

\section{Methodology}

\section{Hybrid energy system configuration}

The hybrid system model is the core of the simulation. Apart from correct pricing and optimization, the quality and accuracy of the model and its implementation in the algorithm, greatly determines the usefulness of the simulation results. Fig. 3 shows the proposed hybrid system. Embedded power generation is defined as the interconnection of several distributed generators (PV panels and diesel generator) and a set of batteries. A battery charger is used to convert AC $\left(\mathrm{I}_{\mathrm{ch} \_A C}\right)$ current from the diesel generator to DC $\left(\mathrm{I}_{\mathrm{ch}}\right.$ DC) current to charge the battery and serve the load. A charge regulator is used to control the charge and discharge current from the battery. To serve the load, electrical energy can be produced either directly from PV $\left(\mathrm{I}_{\mathrm{PV}}\right)$, diesel generator $\left(\mathrm{I}_{\mathrm{ch} \_\mathrm{AC}}\right)$, or indirectly from the battery $\left(\mathrm{I}_{\mathrm{bat}}\right)$. The energy generated from all generating technologies (PV and diesel generator) can be directed to serve the load and charge the battery.

\section{Design and simulation}

Numerous studies are published about the optimum economic design of $\mathrm{PV} /$ diesel systems with energy storage in batteries. Wies et al. [2005] presented a simulation work, using Simulink, of a real hybrid PV-diesel-battery system located in Alaska, comparing it with a system using only a diesel generator and another diesel-battery system to supply energy for the same load. Contaminating emissions were evaluated $\left(\mathrm{CO}_{2}, \mathrm{NO}_{\mathrm{X}}\right.$ and particles) for the various cases, comparing the results with those obtained by means of HOMER [HOMER, 2012] software. Additionally, the global efficiency of the system and its costs were 


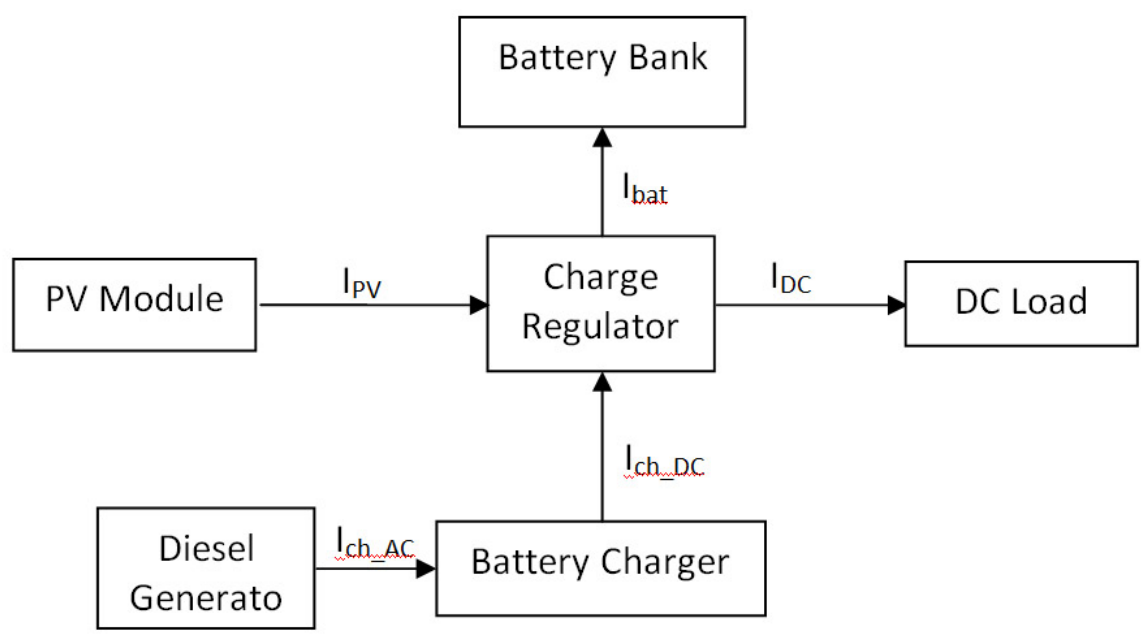

Figure 3 Proposed PV-diesel hybrid system.

determined. The results obtained indicate that the system with only a diesel generator had a lower installation cost, but higher operation and maintenance costs. Additionally, the diesel generator only system was less efficient and released more contaminating emissions than the PV-diesel-battery system.

Shaahid et al. [2009] used HOMER to perform a techno-economic evaluation of $\mathrm{PV} /$ diesel/battery systems for rural electrification in Saudi Arabia. In this study, the effect was examined of the increase in PV/battery on the cost of energy (COE), operational hours of diesel generators and reduction in GHG emissions. Usually, optimum design is carried out by minimizing the Net Present Cost (NPC: investment costs plus the discounted present values of all future costs during the lifetime of the system) or by minimizing the Levelized Cost of Energy (LCE: total cost of the entire hybrid system divided by the energy supplied by the hybrid system).

\section{Control strategies}

In hybrid systems with batteries and without diesel generators, the dispatch strategy is very simple: the battery charges if the renewable energy is in excess after meeting the demand, and the battery discharges if the load exceeds the renewable energy. However, the control strategies of a hybrid system can become very complex if the system includes a diesel generator and batteries [José et al. 2009]. Therefore, it is necessary to determine how the batteries are charged and what element (batteries or diesel generator) has priority to supply energy when the load exceeds the energy generated from renewable sources.

Barley et al. [1995] proposed various strategies for the operation of hybrid PV-diesel-battery systems. One-hour intervals are considered, in which the system parameters remain constant. They also consider ideal batteries, without taking into account losses or the influence of the cycles in their lifespan. Three basic control strategies proposed:

- Zero-charge strategy (Load Following Diesel): the batteries are never charged using the diesel generator. Therefore, the Setpoint of the State of Charge (SOC_Setpoint) is $0 \%$.

- Full cycle-charge strategy: the batteries are charged to $100 \%$ of their capacity every time the diesel generator is on (SOC_Setpoint $=100 \%$ ).

- Predictive control strategy: the charging of the batteries depends on the prediction of the demand and the energy expected to be generated by means of renewable sources, resulting in a certain degree of uncertainty. With this strategy, the energy loss from the renewable energies tends to decrease.

An optimum point for the SOC_Setpoint between 0 and $100 \%$ was used for this study in such a way that the total operation cost of the system was minimal. 
In other words, the strategy lies between zero-charge and full cycle-charge. Barley et al. [1996] improved the control strategies model of Barley et al. [1995], introducing new parameters that have become of great importance in the control strategies of the HOMER software tool. The critical discharge power (Ld) is the value from which the net energy (energy demanded by the charges minus energy supplied by the renewable sources) is more profitable when supplied by means of the diesel generator than when supplied by means of the batteries (having previously been charged by the diesel generator). The authors propose four control strategies:

- Frugal dispatch strategy: if the net demand is higher than Ld, the diesel generator is used. If it is lower, the batteries are used.

- Load following strategy: the diesel generator never charges the batteries.

- SOC_Setpoint strategy: the diesel generator is on at full power, attempting to charge the batteries until the SOC_Setpoint is reached.

- Diesel operation strategy at maximum power for a minimum time (charging the batteries).

Muselli et al. [1999] and [2000] simulate a hybrid PV-diesel-battery system with only DC load in such a way that all the energy from the diesel generator goes through the batteries. The diesel generator works at nominal power, providing that the State of Charge (SOC) of the batteries is within determined limits (Starting threshold (SDM) and Stopping threshold (SAR), in \% of the battery capacity). The decrease in costs obtained with the hybrid system, when compared with the traditional photovoltaic system, is at least 20 or $30 \%$. In addition, it has been concluded that the hybrid PV-diesel-battery system offers greater flexibility and efficiency than the PV-battery system.

In this study, the control strategies used are based on the strategies described by Barley et al. [1995] and used by the HOMER program [HOMER, 2012].

\section{Design of hybrid system}

Designing a hybrid system requires correct compo- nent selection and sizing with appropriate operational strategy [Borowy et al. 1994; Dufo-López et al. 2005]. The design and operational control [Ashari et al. 1999] is not a linear problem due to non-linear component characteristics with a large number of variables [Seeling-Hochmuth, 1998]. Simulation programs are the most common tools for the optimal design of systems like this. By using computer simulation, the optimum configuration can be found by comparing the performance and energy production cost of different system configurations. There are some programs that simulate hybrid systems, as HYBRID2 and HOMER. HYBRID2 simulates hybrid systems with very high precision calculations, but it does not optimize the system. HOMER simulates and optimizes the system.

\section{Choice of the software}

Among the two available software considered, the Hybrid Optimization Model for Electrical Renewables (HOMER) was chosen. It is a user-friendly software that can be easily configured, and is the most complete in terms of managed information. This software is a computer modelling tool based on a genetic algorithm that can evaluate different situations to determine the system configuration that will provide acceptable reliability at the lowest lifecycle cost. In addition to sizing the components of the hybrid system, HOMER also carries out a comparison between two simple dispatch strategies. HOMER's two dispatch strategies are: Load Following and Cycle Charging.

\section{Configuration of the stand-alone energy system}

The design of a stand-alone hybrid system is site-specific and depends on both the resources available and the load demand [Ani et al. 2002]. A typical standalone hybrid diesel-solar PV system has an electricity generation device equipped with the wiring setup and supporting structures, as well as the necessary Balance of System (BOS) components (i.e., the battery bank, the charging controller and the AC/DC 
converter) [Kamaruzzaman et al. 2009]. The energy system proposed for the GSM base station consists of solar PV and diesel power as depicted in Fig. 4. The energy consumption at the base station used in this investigation is $318 \mathrm{kWh} \mathrm{d}^{-1}$ with a $13.3 \mathrm{~kW}$ peak demand load. The energy system consists of a $18 \mathrm{~kW}$ diesel generator, $36 \mathrm{~kW}$ solar PV array, 192 Surrette 6CS25P Battery Cycle Charging, and a $25 \mathrm{~kW} \mathrm{AC/}$ DC converter.

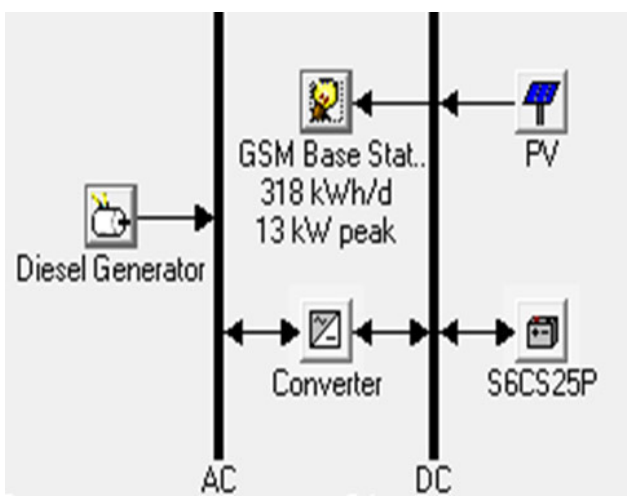

Figure 4 Network architecture of the proposed stand-alone hybrid diesel-solar PV system.

\section{Hybrid PV - diesel energy system controller}

A good operation of a hybrid system can be achieved only by a suitable control of the interaction between the different devices. An exhaustive knowledge of the management strategies to be chosen in the preliminary stage is therefore fundamental to optimize the use of the renewable sources, minimize the wear of batteries, and consume the smallest possible quantity of fossil fuel [Seeling-Hochmuth, 1997; Seeling, 1995]. A control strategy consists of certain predetermined control settings that are set when installing the system. Such settings concern the timing of when to switch on the diesel or not, based on certain values representing the system state, such as the battery state of charge and demand placed on the system.

In this study, the PV power (Ppv) generation is the primary source of energy, the battery $\left(\mathrm{E}_{\text {char }}\right.$ max,disch_max) as the supplement and the diesel generator power $\left(\mathrm{P}_{\mathrm{DG}}\right)$ as the backup source of energy. Fig. 5 outlines the flow between the different modes. The system uses solely the energy generated by the PV panels to supply the load $\left(\mathrm{E}_{\mathrm{L}}\right)$. When the PV panels produces an excess of what is needed by the load, this excess energy can be used to charge the battery $\left(\mathrm{E}_{\text {char }}\right.$ $\max )$. During the charging of the battery, if the excess energy from the PV is less than the battery charging $\left(\mathrm{E}_{\text {char_max }}\right)$, then there will be no excess energy (E.E), but if the excess energy from the PV is greater than the battery charging $\left(\mathrm{E}_{\text {char_max }}\right)$, then the excess energy will be calculated by the system. The loss of power supply (LPS) is equal to zero; meaning that the load will always be satisfied.

On the other way round, if the energy supplied by the PV panels is not sufficient to supply the load, then the system goes to the decision mode (SOC < or $\geq$ than SOC\%) where the program determines what element (batteries or diesel generator) has priority to supply energy using decision rules. The program determines what element has priority to supply energy based on these two conditions:

- If the SOC of the battery is greater than the minimum amount and therefore the battery is able to supply power to the load, then the battery will be used.

- If the load cannot be supplied by the energy source i.e. the power of the PV panels is not sufficient to supply the load and the battery is at its minimum SOC and therefore cannot be used to supply the deficit of power required, then the diesel generator will be used to supply the load and charge the battery.

From this control simulation one will be able to see the performance of the system over the course of the year to see which modes the system spends most time in, the power supplied by each of the energy sources over the year, and the power required by the load over the year. This is a very useful strategy to check how the system is being supplied with power.

\section{Hybrid system components}

\section{Photovoltaic module}

The PV modules used were polycrystalline photovoltaic module with $140 \mathrm{~W}$ maximum power. The pho- 


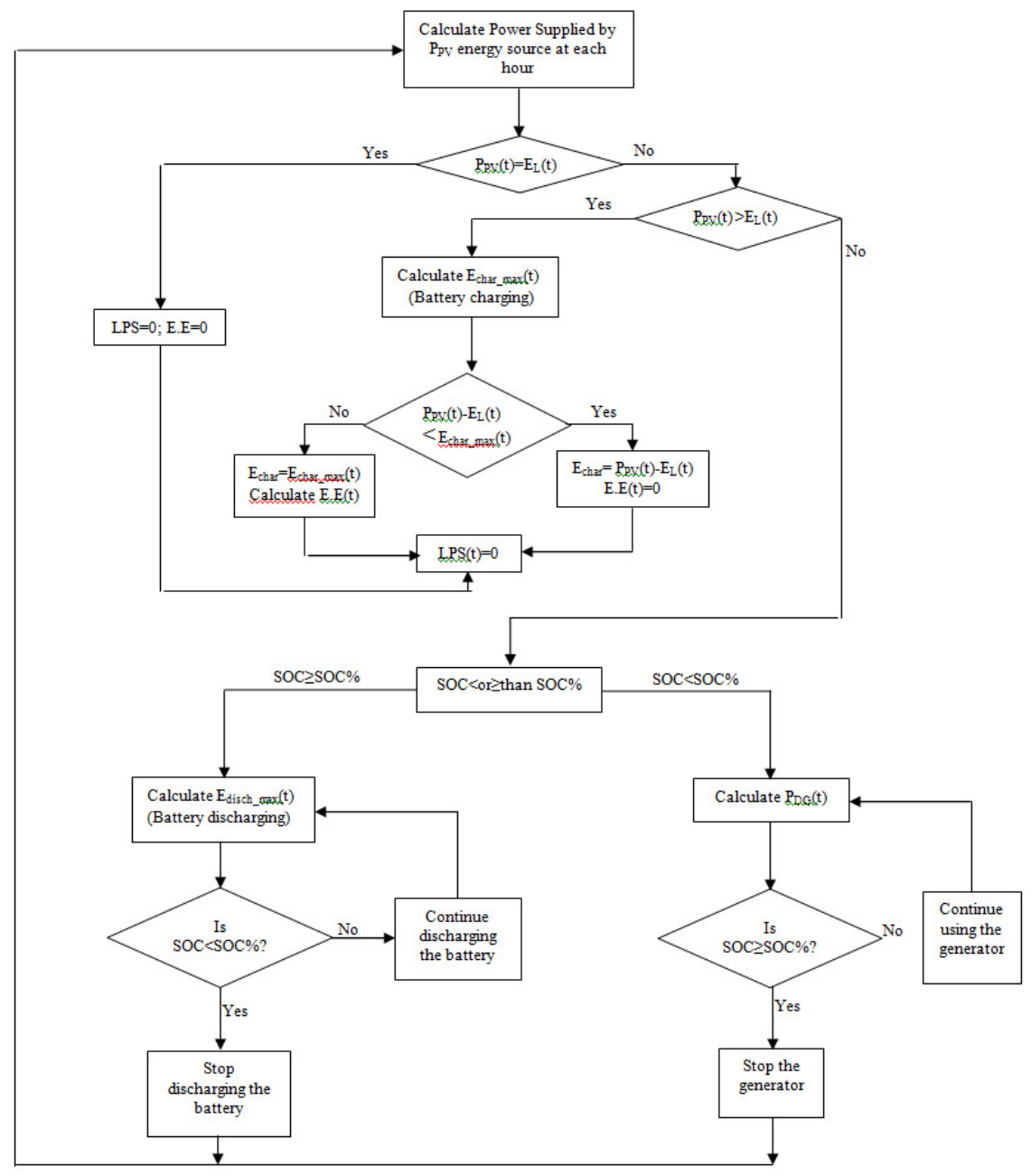

Figure 5 Decision strategy for the hybrid PV - diesel energy system controller

[Ani, 2013c]..

tovoltaic system was considered to have no tracking system for the purpose of the study in order to determine the worst case resource from the site.

\section{Diesel generator}

Diesel generator technology is widespread and the development of the power plant is relatively easy. The price of diesel fuel is N $165\left(\$ 1.0 \mathrm{~L}^{-1}\right)$ based on federal government approved pump prices in Nigeria in July, 2012. This price varies considerably based on region, transportation costs, and current market price. The diesel back-up system is operated at times when the output solar system fails to satisfy the load and when the battery storage is depleted.

\section{Storage battery}

The variations of solar energy generation do not match the time distribution of the demand. The storage battery chosen was a Surrette 6CS25P. From the datasheet given by HOMER software, the minimum state of charge of the battery is $40 \%$. Its round trip efficiency is $80 \%$. Batteries are considered as a major cost factor in small-scale stand-alone power systems.

\section{Converter}

A converter is used which functions as an inverter and rectifier depending on the direction of power flow. In the present case, the size of the converter ranges from 0 to $50 \mathrm{~kW}$ for simulation purposes. 


\section{Economics and constraints}

The project lifetime is estimated at 25 years. The annual interest rate is fixed at $6 \%$. There is no capacity shortage for the system and the operating reserve as a percentage of hourly load was $10 \%$. Meanwhile, the operating reserve as a percentage of solar power output was $25 \%$. Operating reserve is the safety margin that helps ensure reliability of the supply despite variability in electric load, and solar power supply.

\section{System economics}

The capital costs for all system components including PV module, diesel generator, rectifier, battery and balance of system prices are based on quotes from PV system suppliers in Nigeria [Solarshopnigeria, 2012]. These costs are estimates based on a limited number of internet inquiries and prices. They are likely to vary for the actual system quotes due to market factors. The figures used in the analysis are therefore indicative.

The replacement costs of equipment are estimated to be $20 \%-30 \%$ lower than the initial costs, but because decommissioning and installation costs need to be added, it was assumed that they are the same as the initial costs.

The PV array, diesel generator, rectifier and battery maintenance costs are estimates based on approximate time ( $25 \mathrm{yrs}$ ) required for the GSM base station site. All initial costs including installation and commissioning, replacement costs, operating and maintenance costs at the GSM base station site are summarized in Table 4. As HOMER calculates in US Dollars (\$), all costs have been converted from Naira
(N) into USD (\$) as shown in Table 4 using the equivalent as 1US Dollar (\$) equal to N162 of Nigerian currency [Exchange rate, 2012]. All costs presented are in US Dollar (\$).

Inputs to the HOMER software in simulation has been described (the technical and economic data of all the components of the hybrid system).

\section{Simulation results}

The simulations provide information concerning the electricity production, economic costs and environmental characteristics of each system, such as the $\mathrm{CO}_{2}$ emissions. The obtained results are presented in Tables 5, 6, 7 and 8. The detailed analyses obtained at the end of the simulations are described below:

\section{Existing system}

The existing system (diesel generator) has the lowest initial capital cost, high operating cost, high annual cost and high total net present cost for the whole project as shown in Figs. 6, and 8, and Table 5. Furthermore, this system emits more $\mathrm{CO}_{2}$, particulate matter $(\mathrm{PM})$ and $\mathrm{NO}_{\mathrm{X}}$ as a result of burning large amounts of fossil fuel, with a low efficiency operation of $29.7 \%$ as shown in Tables 7 and 8 .

\section{Proposed hybrid system}

The solar PV-diesel system can potentially supply renewable energy of up to $45 \%$ of the energy demand in the base station site as shown in Table 6. The solar PV-diesel system has less annual and total net present cost as a result of less fuel consumption and higher

Table 4 Summary of initial system costs, replacement costs and operating and maintenance costs.

\begin{tabular}{|c|c|c|c|}
\hline Item & Initial system costs & Replacement costs & Operating and maintenance costs \\
\hline PV modules & A 324/W (\$2) & \# 291.6/W (\$1.8) & \# 16,200/kW/yr (\$100) \\
\hline $18 \mathrm{~kW}$ diesel generator & $\mathrm{N} 2,106,000(\$ 13,000)$ & N 2,106,000 $(\$ 13,500)$ & A $405 / \mathrm{hr}(\$ 2.5)$ \\
\hline Surrete 6CS25P battery & $\mathrm{N} 185,490(\$ 1,145)$ & $\mathbb{N} 162,000(\$ 1,000)$ & A 16,200 (\$100) \\
\hline Converter & $A 324 / W(\$ 2)$ & \# 324/W (\$2) & A 16,200/kW/yr (\$100) \\
\hline
\end{tabular}




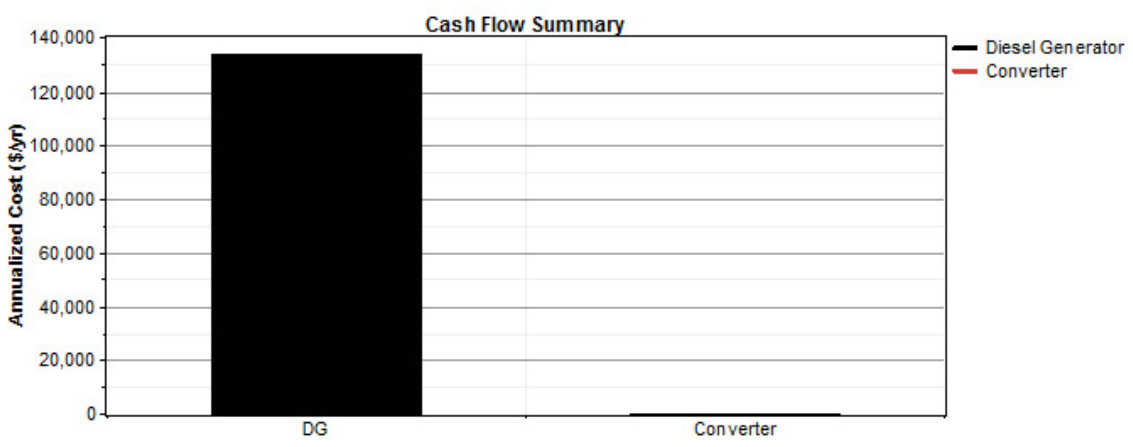

Figure 6 Annualized cost of component of existing diesel only system.

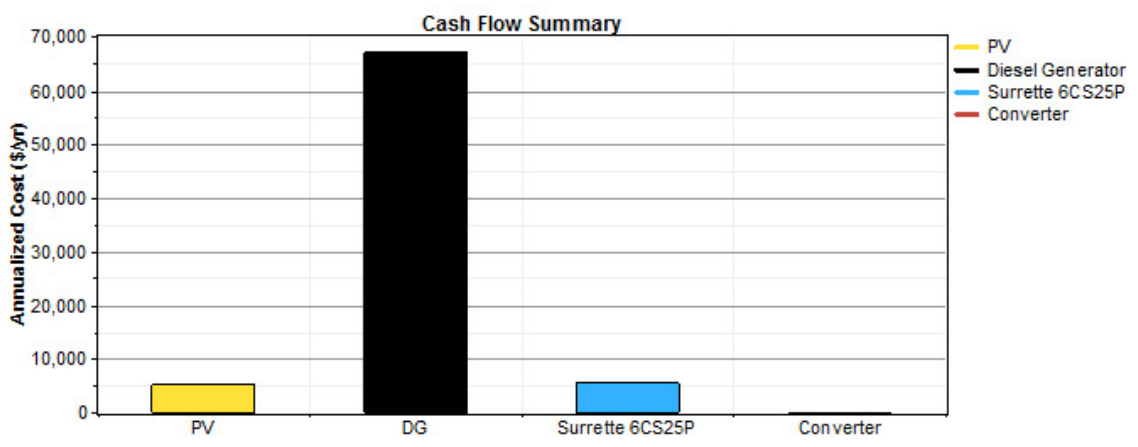

Figure 7 Annualized cost of component of optimized hybrid diesel- solar PV energy system.

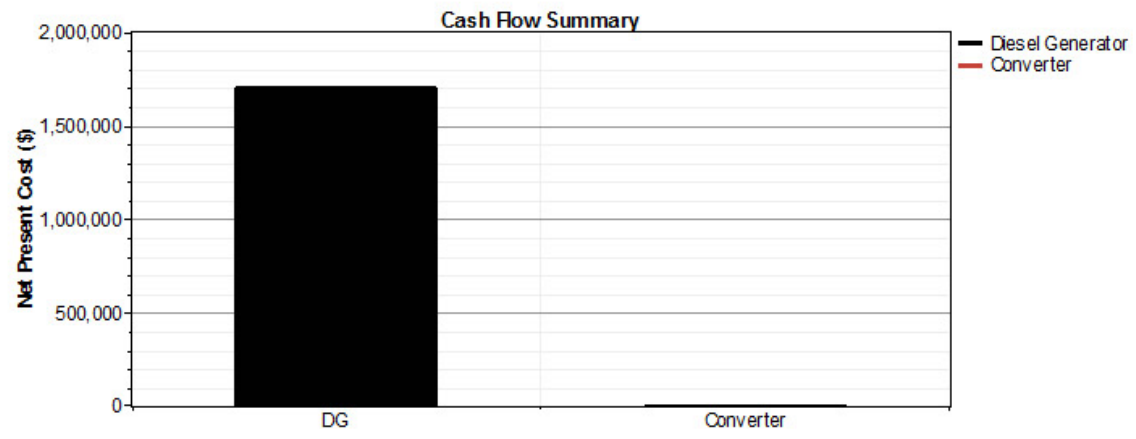

Figure 8 Net present cost of component of existing diesel only system.

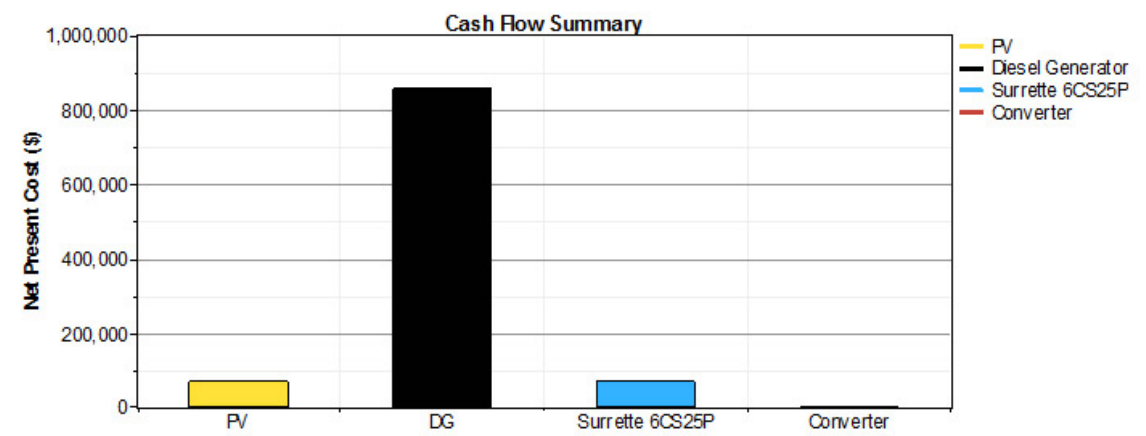

Figure 9 Net present cost of component of optimized hybrid diesel- solar PV energy system. 


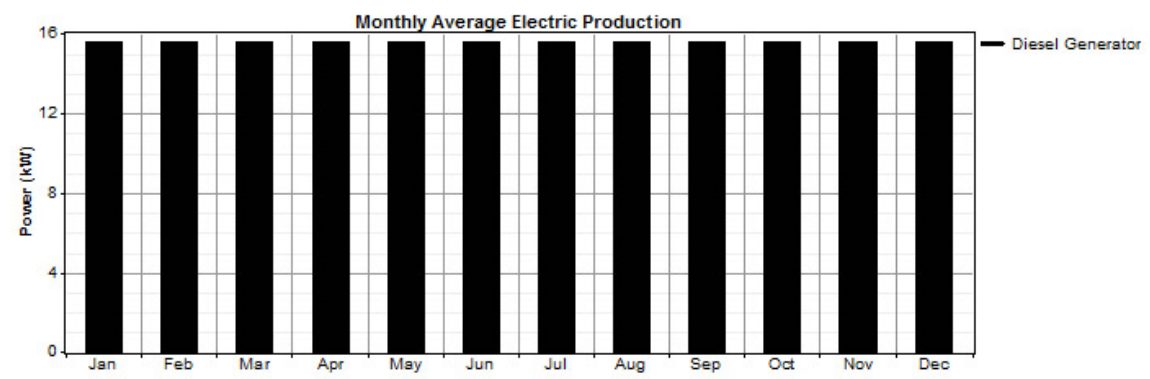

Figure 10 Electrical production of diesel only energy system.

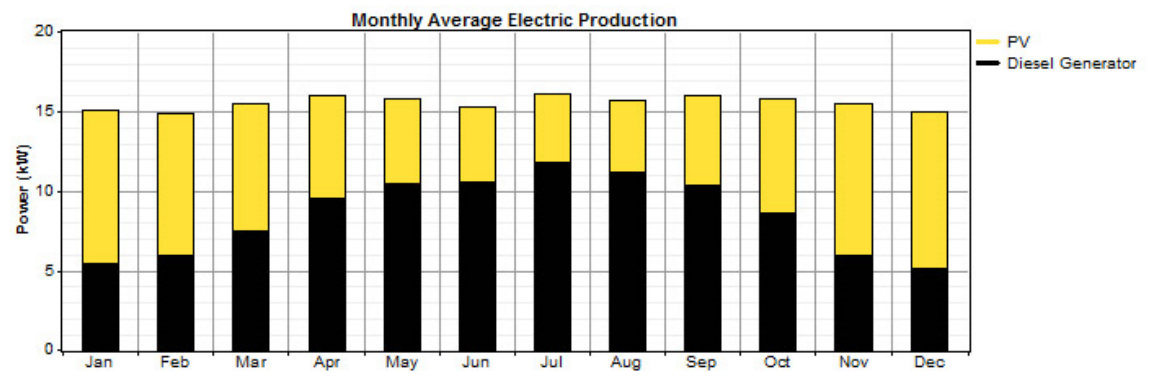

Figure 11 Electrical production of hybrid diesel-solar PV energy system.

efficiency operation of $30.7 \%$ from the diesel genset as shown in Figs. 7 and 9, and Table 8. Reducing fuel consumption also means less emissions from the energy system as shown by the solar PV-diesel system, which has the lowest emission of $\mathrm{CO}_{2}, \mathrm{PM}$ and $\mathrm{NO}_{\mathrm{X}}$ as shown in Table 7.

Table 5 Comparison of simulation results of economic.

\begin{tabular}{|cccc|}
\hline Parameter & Units & $\begin{array}{c}\text { Existing } \\
\text { system } \\
\text { diesel only }\end{array}$ & $\begin{array}{c}\text { Proposed hybrid } \\
\text { diesel-solar PV } \\
\text { system }\end{array}$ \\
\hline Initial cost & USD(\$) & 21,850 & 123,370 \\
\hline $\begin{array}{c}\text { Operating } \\
\text { cost }\end{array}$ & USD(\$) $\mathrm{yr}^{-1}$ & 132,228 & 68,245 \\
\hline $\begin{array}{c}\text { Annualized } \\
\text { cost }\end{array}$ & USD(\$) $\mathrm{yr}^{-1}$ & 133,938 & 77,896 \\
\hline Total NPC & USD(\$) & $1,712,171$ & 995,774 \\
\hline
\end{tabular}

\section{Electricity production}

The existing system (diesel only) produces 136,550

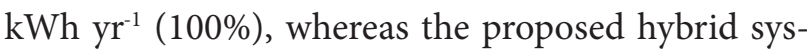
tem (diesel-solar PV) produces 61,151 $\mathrm{kWh} \mathrm{yr}^{-1}(45 \%)$

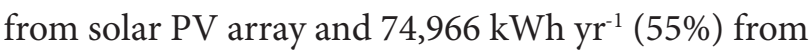
diesel generator making a total of $136,116{\mathrm{kWh} \mathrm{yr}^{-1}}^{-1}$ (100\%) as shown in Figures 10 and 11, respectively. The load demand is $116,068 \mathrm{kWh} \mathrm{yr}^{-1}$, while the excess electricity from the existing system is $20482 \mathrm{kWh}$ $\mathrm{yr}^{-1}(15 \%)$ and the proposed project has excess electricity of $20048 \mathrm{kWh} \mathrm{yr}^{-1}(15 \%)$ as shown in Table 6.

Excess electricity generated by the proposed hybrid PV-diesel system.

The excess of electricity occurs slightly in all months, but occurs most in November (as can be clearly seen in Fig. 12).

Excess energy = Total energy Production - Total energy Consumption Eq. (1)

Excess energy $=(136,116-116,068) \mathrm{kWh}_{\mathrm{Wear}}{ }^{-1}=$ $20,048 \mathrm{kWh}$ year $^{-1}$. 
Table 6 Comparison of simulation results of electricity production $\left(\mathrm{kWh} \mathrm{yr}^{-1}\right)$.

\begin{tabular}{|c|c|c|c|c|}
\hline \multirow{2}{*}{ Quantity } & \multicolumn{2}{|c|}{ Diesel only } & \multicolumn{2}{|c|}{ Diesel in hybrid system (diesel-solar PV) } \\
\hline & kWh yr-1 & $\%$ & kWh yr-1 & $\%$ \\
\hline \multicolumn{5}{|l|}{ Load } \\
\hline DC primary load & 116,068 & 100 & 116,068 & 100 \\
\hline \multicolumn{5}{|l|}{ Production } \\
\hline PV array & None & None & 61,151 & 45 \\
\hline Diesel generator & 136,550 & 100 & 74,966 & 55 \\
\hline Total energy & 136,550 & 100 & 136,116 & 100 \\
\hline Excess electricity & 20482 & 15 & 20048 & 15 \\
\hline
\end{tabular}

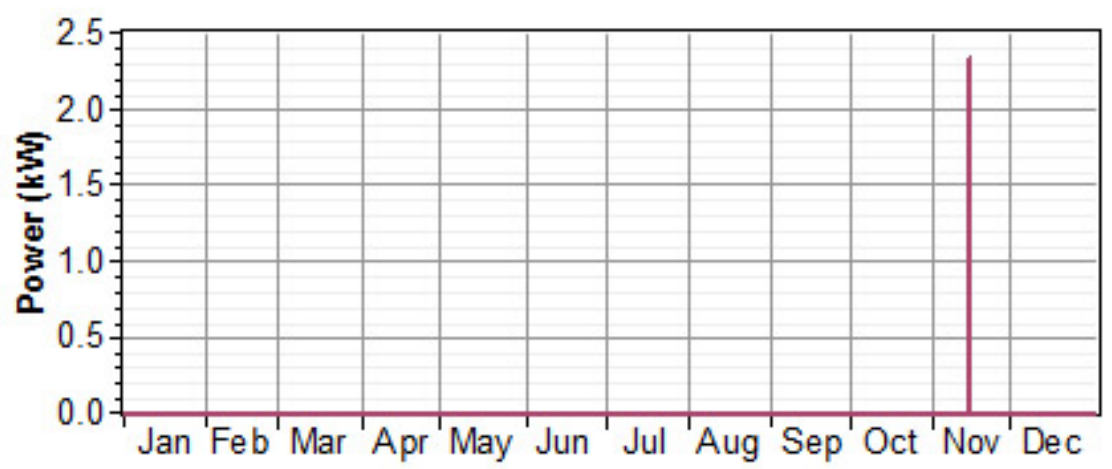

Figure 12 Excess electricity generated by the hybrid PV/diesel energy system.

This excess electricity of about $15 \%$ power supply is guaranteed in the location simulated in order to charge phones. Also, it can be sold to the community where the site is located. The sale of this excess electricity will offer a promising approach for the network operators to mitigate operations and maintenance costs of the hybrid system.

Optimization analysis carried out by HOMER shows that the optimum energy system is the combination of the the $18 \mathrm{~kW}$ diesel generator, $36 \mathrm{~kW}$ solar PV array, 192 Surrette 6CS25P Battery Cycle Charging, and a $25 \mathrm{~kW} \mathrm{AC/DC} \mathrm{converter.} \mathrm{This} \mathrm{can}$ be shown in Fig. 13 which shows a complete list of HOMER solutions from the the most optimum to the least optimum.

\section{Discussions}

\section{Economic Cost}

Two types of costs were used to compare the diesel only and PV-diesel hybrid system. They are: annual cost of operation and total NPC.

The annual cost of a system is the yearly value of all the costs that it incurs in a year. The diesel-only system has an annual cost of $\$ 133,938$, while the PVdiesel hybrid system has an annual cost of $\$ 77,896$, as shown in Figs. 6 and 7, respectively. This system (proposed) saves $\$ 56,042$ to the network operator annually, when compared with the diesel-only system.

The total NPC of a system is the present value of all the costs that it incurs over its lifetime, minus the present value of all the revenue that it earns over its lifetime. Revenue includes salvage value. Diesel- 
Table 7 Comparison of simulation results of emissions from existing and proposed system.

\begin{tabular}{|lcc|}
\hline & \multicolumn{2}{c|}{ Emissions } \\
\hline Pollutant & Existing system diesel only & Proposed project diesel-solar PV system \\
\hline Carbon dioxide & Ton $\mathrm{yr}^{-1}$ & ${\text { Ton } \mathrm{yr}^{-1}}^{-1}$ \\
\hline Carbon monoxide & 123.105 & 65.270 \\
\hline Unburned hydrocarbons & 0.304 & 0.161 \\
\hline Particulate matter & 0.0337 & 0.0178 \\
\hline Sulfur dioxide & 0.0229 & 0.0121 \\
Nitrogen oxides & 0.247 & 0.131 \\
\hline
\end{tabular}

\begin{tabular}{|c|c|c|c|c|c|c|c|c|c|c|c|c|}
\hline$\varphi \mathrm{Q}$ & $\begin{array}{l}\text { PV } \\
\text { (kW) }\end{array}$ & $\begin{array}{l}\mathrm{DG} \\
(\mathrm{kW})\end{array}$ & S6CS25P & $\begin{array}{l}\text { Conv. } \\
\text { (kW) }\end{array}$ & $\begin{array}{l}\text { Initial } \\
\text { Capital }\end{array}$ & $\begin{array}{l}\text { Operating } \\
\text { Cost }(\$ / y r)\end{array}$ & $\begin{array}{l}\text { Total } \\
\text { NPC }\end{array}$ & $\begin{array}{c}\mathrm{COE} \\
(\$ / \mathrm{kW} / \mathrm{h})\end{array}$ & $\begin{array}{l}\text { Ren. } \\
\text { Frac. }\end{array}$ & $\begin{array}{c}\text { Diesel } \\
\text { (L) }\end{array}$ & $\begin{array}{c}\mathrm{DG} \\
\text { (hrs) }\end{array}$ & $\wedge$ \\
\hline 甲⿴囗十 & 36.0 & 18 & 192 & 25 & $\$ 123,370$ & 68,245 & $\$ 995,774$ & 0.671 & 0.45 & 24,786 & 4,198 & \\
\hline 3 田 & 36.0 & 18 & 192 & 50 & $\$ 123,420$ & 68,346 & $\$ 997,109$ & 0.672 & 0.45 & 24,786 & 4,198 & \\
\hline 园 & 36.0 & 18 & 96 & 25 & $\$ 103,210$ & 70,567 & $\$ 1,005,297$ & 0.678 & 0.44 & 25,594 & 4,472 & \\
\hline 团 & 36.0 & 18 & 96 & 50 & $\$ 103,260$ & 70,668 & $\$ 1,006,632$ & 0.678 & 0.44 & 25,594 & 4,472 & \\
\hline 园 & 36.0 & 18 & 48 & 25 & $\$ 93,130$ & 81,559 & $\$ 1,135,722$ & 0.765 & 0.43 & 28,154 & 5,390 & \\
\hline 园 & 36.0 & 18 & 48 & 50 & $\$ 93,180$ & 81,659 & $\$ 1,137,057$ & 0.766 & 0.43 & 28,154 & 5,390 & \\
\hline 世 & 36.0 & 18 & 24 & 25 & $\$ 88,090$ & 95,981 & $\$ 1,315,045$ & 0.886 & 0.41 & 31,825 & 6,510 & \\
\hline 즌 & 36.0 & 18 & 24 & 50 & $\$ 88,140$ & 96,081 & $\$ 1,316,380$ & 0.887 & 0.41 & 31,825 & 6,510 & \\
\hline & 12.0 & 16 & 48 & 25 & $\$ 49,930$ & 102,777 & $\$ 1,363,760$ & 0.919 & 0.15 & 38,614 & 7,321 & \\
\hline & 12.0 & 16 & 48 & 50 & $\$ 49,980$ & 102,877 & $\$ 1,365,095$ & 0.920 & 0.15 & 38,614 & 7,321 & \\
\hline$\pi$ & 12.0 & 16 & 96 & 25 & $\$ 60,010$ & 103,083 & $\$ 1,377,757$ & 0.929 & 0.15 & 38,531 & 7,298 & \\
\hline $5 \pi$ & 12.0 & 16 & 96 & 50 & $\$ 60,060$ & 103,184 & $\$ 1,379,092$ & 0.929 & 0.15 & 38,531 & 7,298 & \\
\hline 甲⿴囗十 & 12.0 & 16 & 24 & 25 & $\$ 44,890$ & 104,574 & $\$ 1,381,703$ & 0.931 & 0.15 & 38,668 & 7,554 & \\
\hline תו & $10 n$ & in & $9 x$ & en & a A A n & $10 x+75$ & *1 1 กา $\mathrm{mn}$ & ก & $n+5$ & an $\mathrm{rm}$ & 750. & $\underline{v}$ \\
\hline
\end{tabular}

Figure 13 Overall optimization results of HOMER selected solutions.

only has a total NPC of $\$ 1,712,171$, operating cost of $\$ 132,228$, and initial cost of $\$ 21,850$ while the PVdiesel has total NPC of $\$ 995,774$, operating cost of $\$ 68,245$, and initial cost of $\$ 123,370$ as shown in Figs. 7 and 8 , respectively and Table 5 . The proposed saves $\$ 716,397$ to the network operator when compared with the diesel-only system.

A base case system (diesel-only) was selected and compared to the current system (proposed hybrid $\mathrm{PV} /$ diesel system); to find the present value of fuel saved by installing a hybrid system instead of a dieselonly system, taking into account the cost of installation, operation, and maintenance of each system. The present value as shown in Table 9, is the difference between the NPCs of the base case system and the current system. The sign of the present value indicates whether the current system compares favorably as an investment option with the base case system or not. A positive value $(\$ 716,397)$ indicates that the current system saves money over the project lifetime compared to the base case system.

Payback is defined as the number of years at which the cumulative cash flow of the difference between the current system and base case system changes from negative to positive. The payback is an indication of how long it takes to recover the difference in investment costs between the current system and the base case system. The results of the economic compa- 
Table 8 Comparison of simulation of existing system (diesel only) and proposed hybrid system (diesel-solar PV).

\begin{tabular}{|lccc|}
\hline Quantity & Units & Diesel only & Diesel-solar PV \\
Operational life & & Value & Value \\
\hline Capacity factor & $\mathrm{yr}$ & 2.28 & 4.76 \\
\hline Hours of operation & $\%$ & 86.6 & 47.5 \\
\hline Fuel consumption & $\mathrm{hr} \mathrm{yr}^{-1}$ & 8,760 & 4,198 \\
\hline Fuel energy input & $\mathrm{L} \mathrm{yr}^{-1}$ & 46,749 & 24,786 \\
\hline Mean electrical efficiency & $\mathrm{kWh} \mathrm{yr}^{-1}$ & 460,007 & 243,897 \\
\hline
\end{tabular}

risons of the selected energy system (diesel only and hybrid PV/diesel system) are shown in Table 9.

Therefore, in the short term and in the long term, for the project of power generation at the base station site, the hybrid system is still the best option from an economic perspective.

\section{Electricity Production}

The existing system (diesel only system) supplies $100 \%$ of the total electricity demand with a capacity factor [capacity factor is the average power output of the energy system divided by its nominal capacity] of $86.6 \%$; while in the hybrid PV-diesel system, the PV system has a capacity factor of $19.4 \%$ and supplies $45 \%$ of the annual electricity production, whereas the diesel generator contributes $55 \%$ of the total electricity with a capacity factor of $47.5 \%$. The hybrid PV-

Table 9 Metric table showing economic measures of the selected energy system (diesel only and hybrid PV/diesel system).

\begin{tabular}{|ll|}
\hline Metric & Value \\
\hline Present worth & $\$ 716,397$ \\
\hline Annual worth & $\$ 54,041 \mathrm{yr}^{-1}$ \\
\hline Return on investment & $62.9 \%$ \\
\hline Internal rate of return & $65.1 \%$ \\
\hline Simple payback & $1.63 \mathrm{yrs}$ \\
\hline Discount payback & $1.77 \mathrm{yrs}$ \\
\hline
\end{tabular}

diesel system can utilized renewable energy (PV) to supply 45\%, as shown in Table 6 and Fig. 11.

\section{Environmental Pollution}

The diesel-only system operating for $8,760 \mathrm{~h}^{\text {annum }}{ }^{-1}$ has a fuel consumption of $46,749 \mathrm{~L}$ annum ${ }^{-1}$. It generates 123.105 tonnes of $\mathrm{CO}_{2}, 0.304$ tonnes of $\mathrm{CO}$, 0.0337 tonnes of UHC, 0.0229 tonnes of PM, 0.247 tonnes of $\mathrm{SO}_{2}$, and 2.711 tonnes of $\mathrm{NO}_{\mathrm{X}}$ as shown in Table 7. In contrast, in the hybrid PV-diesel system, the diesel generator operates for $4,198 \mathrm{~h}^{2}$ annum$^{-1}$, and has a fuel consumption of $24,786 \mathrm{~L}^{2}$ nnum ${ }^{-1}$. This system emits 65.270 tonnes of $\mathrm{CO}_{2}, 0.161$ tonnes of $\mathrm{CO}$, 0.0178 tonnes of UHC, 0.0121 tonnes of PM, 0.131 tonnes of $\mathrm{SO}_{2}$, and 1.438 tonnes of $\mathrm{NO}_{\mathrm{X}}$ annually into the atmosphere at the location of the base station site as shown in Table 7. This option shows an almost $45 \%$ decrease in each pollutant that is due to a $45 \%$ renewable penetration into the existing diesel-only power system. The reduction in the quantity of different air pollutants for $45 \%$ renewable penetration compared to that diesel only are thus: 57.835 tonnes of $\mathrm{CO}_{2}, 0.143$ tonnes of $\mathrm{CO}, 0.0159$ tonnes of UHC, 0.0108 tonnes of $\mathrm{PM}, 0.116$ tonnes of $\mathrm{SO}_{2}$, and 1.273 tonnes of $\mathrm{NO}_{\mathrm{X}}$. Moreover, from the standpoint of fuel consumption, this hybrid system saves 21,963 litres of fuel per year to the network operator when compared with the diesel-only system.

In summary, the diesel-only system has the least initial capital cost, but in the end has the highest total 
net present cost over its lifespan. While the PV/diesel hybrid system requires higher initial capital cost, over the lifespan of the systems, it has a less total net present cost as a result of less fuel consumption.

\section{Conclusion}

This study concludes that using a PV/diesel hybrid system to power GSM base station sites is far better than the diesel only system, especially in areas where there is no utility power.

The economic analysis of hybrid PV/diesel standalone systems carried out in this paper verifies the predictions for the brilliant future of hybrid energy technology for network operators in Nigeria. The results show that the cost of hybrid PV/diesel systems, though very high during installation (initial cost), have lower overall costs throughout the lifespan of the system.

From an environmental standpoint, in terms of pollutant emission, the hybrid $\mathrm{PV} /$ diesel system is preferred over the diesel generator. The control algorithm designed takes full advantage of the solar energy when it is available, and minimizes diesel fuel consumption, thereby reducing pollution. If the diesel-only generator is continued to be used by network operators in Nigeria, the $\mathrm{CO}_{2}$ generated in each base station location based on the simulation results will possibly cause global warming in the near future. From the simulation results (costs and emissions), it is demonstrated that the use of a hybrid PV/diesel system with battery achieves significantly lower NPC and reduction on $\mathrm{CO}_{2}$, as compared to a standalone diesel system. Therefore, the suitability of hybrid PV/ diesel system with battery in the telecommunications industry was determined in the perspective of technical and economical analysis. As a conclusion, the hybrid PV/diesel system has potential use for power generation at GSM base station sites in Nigeria.

\section{References}

Ani, V.A. and Emetu, A.N. (2013). Estimation of environmental impact of power generation at GSM base station site. Electronic Journal of Energy and Environment. vol. 1, no 1, (In Press). DOI:10.7770/ ejee-V1N1-art479

Ani, V.A. (2013a). Optimal operational strategy for hybrid power generation at GSM base station site. International Journal of Energy Optimization and Engineering. (In Press).

Ani, V.A. (2013b). Simulation and optimization of stand-alone photovoltaic/diesel hybrid system for banking industry. Int. Journal of Energy Optimization and Engineering. (In Press).

Ani, V.A.; Nzeako, A.N. and Obianuko, J.C. (2012). Energy optimization at datacenters in two different locations of Nigeria. International Journal of Energy Engineering. vol. 2, no 4, 151-164. doi: 10.5923/j.ijee.20120204.07.

Ani, V.A. and Nzeako, A.N. (2012). Energy optimization at GSM base station sites located in rural areas. International Journal of Energy Optimization and Engineering. vol.1, $\mathrm{n}^{\circ} 3,1-31$. DOI: 10.4018/ijeoe.2012070101.

Ashari, M. and Nayar, C.V. (1999). An optimum dispatch strategy using set points for a photovoltaic (PV)-diesel-battery hybrid power system. Solar Energy. vol. 66, no 1, 1-9.19.

Bala, E.J.; Ojosu, J.O. and Umar, I.H. (2000). Government policies and programmes on the development of solar PV sub-sector in Nigeria. Nigeria Journal of Renewable Energy. vol. 8, 1-6.

Barley, C.D. and Winn, C.B. (1996). Optimal dispatch strategy in remote hybrid power systems. Solar Energy. vol. 58, 165-79.

Barley, C.D.; Winn, C.B.; Flowers, L. and Green, H.J. (1995). Optimal control of remote hybrid power systems. Part I. Simplified model. In: Proceedings of WindPower'95.

Bernal-Agustín, J.L. and Dufo-López, R. (2009). Simulation and optimization of stand-alone hybrid renewable energy systems. Renewable and Sustainable Energy Reviews. vol. 13, 2111-2118.

Borowy, B.S. and Salameh, Z.M. (1994). Optimum photovoltaic array size for a hybrid wind/PV system. IEEE Transaction on Energy Conversion. vol. $9, n^{\circ} 3,482-488$. 
Dufo-López, R. and Bernal-Augustin, J.L. (2005). Design and control strategies of PV-diesel systems using genetic algorithm. Solar Energy. vol. 79, 3346.

Falade, T.S. (1995). Solving Housing Problems in Lokoja. B.Sc. Research Report. Department of Architecture, A.B.U. Zaria.

Faruk, N.; Ayeni, A.A.; Muhammad, M.Y.; Abdulkarim, A. and Moses, O. (2012). Hybrid power systems For Cell Sites in Mobile Cellular Networks. Cyber Journals: Multidisciplinary Journals in Science and Technology, Journal of Selected Areas in Renewable and Sustainable Energy (JRSE), January Edition.

Kamaruzzaman, S.; Ahmad, F.; Mohd, H.R.; Mohd, Y.S.; Mohammad, A.A.; Muhammad, Y.; Nowshad, A.; Lim, C.H. and Azami, Z. (2009). Optimization of a stand-alone wind/PV hybrid system to provide electricity for a house in Malaysia. Proceedings of the 4th IASME/WSEAS International Conference on ENERGY \& ENVIRONMENT.

Muselli, M.; Notton, G. and Louche, A. (1999). Design of hybrid-photovoltaic power generator, with optimization of energy management. Solar Energy. vol. 65, n 3, 143-157.

Muselli, M.; Notton, G.; Poggi, P. and Louche, A. (2000). PV-hybrid power systems sizing incorporating battery storage: an analysis via simulation calculations. Renewable Energy. vol. 20, 1-7.

Ojo, O. (2000). Fundamentals of Physical and Dynamic Climatology. 1st ed., SEDEC Publ., Lagos, Nigeria.

Seeling, G. C. (1995). Optimization of PV-hybrid energy system design and system operation control using genetic algorithms; in Proc. of the 13th EC PV Conference, Nice, France, pp. 4.

Seeling-Hochmuth, G.C. (1998). Optimization of hybrid energy systems sizing and operation

Control. A Dissertation presented to the University of Kassel in Candidacy for the Degree of Dr.-Ing.

Seeling-Hochmuth, G. (1997). A combined optimization concept for the design and operation strategy of hybrid PV energy systems. Solar Energy. vol. $61, \mathrm{n}^{\circ} 2,77-87$.
Shaahid, S.M. and El-Amin, I. (2009). Technoeconomic evaluation of off-grid hybrid photovoltaic-diesel-battery power systems for rural electrification in Saudi Arabia-a way forward for sustainable development. Renewable and Sustainable Energy Reviews. vol. 13, no 3, 625-633. http://dx.doi.org/10.1016/j.rser.2007.11.017.

Wichert, B. (1997). PV-diesel hybrid energy systems for remote area power generation - a review of current practice and future developments. Renewable and Sustainable Energy Reviews. vol. 1, no 3, 209-28.

Wies, R.W.; Johnson, R.A.; Agrawal, A.N. and Chubb, T.J. (2005). Simulink model for economic analysis and environmental impacts of a PV with diesel-battery system for remote villages. IEEE Trans Power Systems. vol. 20, no 2, 692-700.

Yu, H.; Pan, J. and Xiang, A. (2005). A multi-function grid-connected PV system with reactive power compensation for the grid. Solar Energy. vol. 79, $\mathrm{n}^{\circ} 1,101-6$.

\section{Web Page}

ALCATEL-LUCENT Strategic White Paper: Ecosustainable wireless service. Source: www.alcatellucent.com

Btu Definition and Calculate Btu. http://www.aircontalk.com/BtuDefinition-CalculateBtu.html.

Exchange rate for converting United States Dollar to Nigerian Naira: 1 USD $=161.49739$ NGN. http://themoneyconverter.com/USD/NGN. aspx\#exchange-rates. Last Updated: 07/17/2012 11:00:54.

GSMA. (2009). Environmental Impact of Mobile Communications Networks. Available at: http:// www.gsmworld.com/environment

IT News Africa. (2010). Article on MTN Nigeria wants tough laws to safeguard telecoms industry. Available at: http://www.itnewsafrica. com/2010/08/mtn-nigeria-wants-tough-laws-tosafeguard-telecoms-industry/

Melford, I. (2003). Nigeria: warming up to solar energy, science in Africa, Science magazine for Africa. 
Source: http://www.scienceinafrica.co.za/2003/ november/solar.htm

NASA. National Aeronautics and Space Administration. (2010). http://eosweb.larc.nasa.gov/

Pierre, G. (2006). Power system efficiency in wireless communication, Ericsson. http://www.apec-conf. org/2006/APEC_2006_SP2_1.pdf

Robertson, C. and Romm, J. (2002). Data centres,

power, and pollution prevention: design for business

and environmental advantage. The centre for energy and climate solutions. www.cool-companies.org

Roy, S. (2008). Energy logic for telecommunica- tions. A white paper from the experts in businesscritical continuity, Emerson Network Power. www. EmersonNetworkPower.com/EnergySystems

Solarshopnigeria. (2012). http://www.solarshopnigeria.com/index.php/solar-pv-modules/solarworld-modules/sunmodule-sw-140-poly-r6a.html Vanguard News paper. (2011). visited on 10/12/2011. http://www.vanguardngr.com/2011/12/ airtelgoes--with-e-site/

Willson, J. (2009). Energy \& emissions at cellular base stations. WireIE Holdings International Inc, Canada. Pg.3. Available at: www.wireie.com 